\title{
REDUCING FRICTION IN EMPLOYER-EMPLOYEE RELATIONSHIPS
}

\author{
Benjamin M. Selekman* and Sylvia K. Selekman $\dagger$
}

I

Friction constitutes a pervasive phenomenon in shop relationships. It has, however, received little attention. Concern has centered almost exclusively upon the more familiar and often dramatic "labor dispute." Frictions and disputes, of course, are closely related. Both constitute forms of human behavior-negatively charged behavior-within a specific work environment. Both have their causes, because all human behavior is caused-motivated-by a multiplicity of subjective and objective factors.

But these two related forms of shop behavior also differ one from the other. A dispute represents behavior that has crystallized into a concrete incident. It is embodied in demands, issues, or complaints; it is handled by defined procedures; it is ended by a "settlement." In a word, the conflict, dispute, grievance, or even difference has been formalized. It has become a discrete episode, precipitated out of the continuous flow of shop relations for resolution within a framework of law and custom-the so-called grievance machinery-or by bargaining across the negotiating table, or by a test of strength.

Friction, in contrast, comprises the whole matrix of precursor-behavior that may eventually produce an explicit "dispute." It is fed by all the negative currents of feeling and sentiment entering into the continuous flow of shop relations-the resentments, fears, suspicions, and antagonisms arising in daily dealings in particular shops and stores and mines and mills. Friction contains the ingredients of conflict before they have crystallized into the overt clashes termed disputes.

Friction in the shop thus belongs clearly to the unceasing interaction of management and men in daily work. It portrays a continuing aspect of the dynamics of industrial behavior. The episodic character of disputes, however, makes it unfortunately easy to detach each controversy from its whole context. Indeed, the very pressure for disposing of the specific issues to which a dispute has been "reduced" strengthens the tendency to. isolate the incident from all that has preceded and all that will follow it.

- B.S. Univ. of Pittsburgh, 1915; M.A. 1917, Ph.D. 1927, Columbia Univ. Professor of Labor Relations, Graduate School of Business Administration, Harvard Univ. Author, EMPLovers' Representition in Steel Works (ig24), Sharing Management Witt the Workers (ig24), Employees' Representamon in Conl Mines (with Mary Abby Van Klecch) (I924), Postroning Strikes (1927), British INDUstry Today (with Sylvia K. Selekman) (I929), LAw and LAbor Relations: A Study of the INpustrial Disputes Act of Canade (1936), and contributor to various periodicals.

+ Ph.D. Columbia Univ., 1925. Formerly instructor in Hunter and Barnard Colleges. Fellow, Social Science Research Council, r927-28. Co-author (with Benjamin M. Selekman) of British INDustry TopaY (r929) and of articles in various journals. 
Yet only attention to the dispute, and not the dispute itself, can be detached from the continuing relationships that constitute its context. So dynamic, in fact, are the ties connecting both frictions and disputes with underlying shop relationships that the three are best understood as an integrated sequence in which each emerges as cause and result of the other. Thus the quality of relationships existing in a given shop at a given time determines the degree of daily friction between management and men; such friction in turn precipitates the conflict and controversy we term "disputes"; while the handling of these disputes determines whether or not sharpened resentments and antagonisms will be carried back into the shop, to intensify the frictions of daily working together, and thus to agitate further the atmosphere of joint dealings. A crude diagram indicates the circular flow of influence:

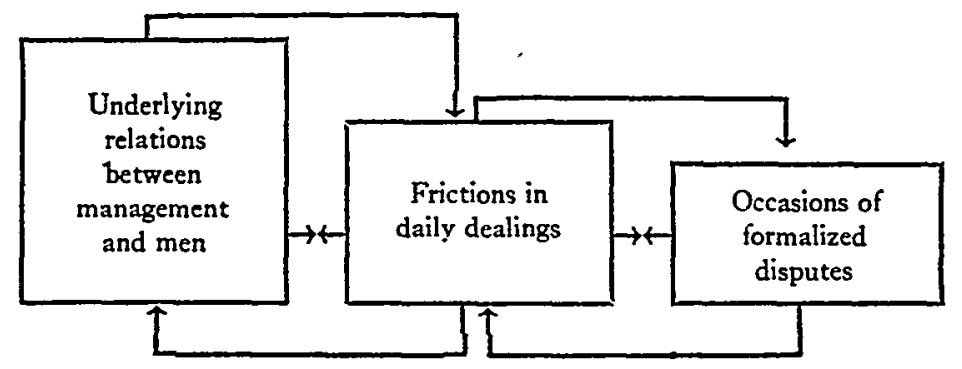

In this dynamic perspective friction in employer-employee relations affords a highly revealing symptom. It offers an index both of the fundamental state of health in the shop community and of potential outbreaks of overt conflict. It is an index, moreover, almost always available in greater or lesser degree. For the important thing to realize about friction is its inevitability. In social as in mechanical operations, it emerges the invariable resistances-one to the other-of bodies in related motion; in the shop as in all social institutions where men combine to promote life-goals, frictions arise from the sheer relationships by which men move forward or act together. Even such dominantly co-operative institutions as the family, the church, the school, are not immune from frictions and the sporadic conflicts they generate. Shall more be expected amid the tensions of modern industry?

\section{II}

The sparks that fly whenever men must act together in pursuit of their own goals are struck in the first instance by the clash of individual aspiration and achievement in the inevitably joint enterprises of social living. Man himself constitutes the first component in friction; it rises in the capacity for hostility he brings to situations in which he feels himself balked. This capacity roots deep in the human endowment. It belongs, in its biologic origins, to the basic protective devices equipping the human animal for survival. For the prime emotions in the constellation of related feelings and ideas that produce hostility are fear and anger-the fear which before 
danger mobilizes an organism for flight and escape, the anger that mobilizes it to fight and resist.

Patently, however, the present-day world seldom confronts man with the physical dangers of primitive times. The threats in modern industrialism rise predominantly from the social relationships by which alone man can survive in it. These relationships, from infancy throughout life, yield both the means for satisfying and the obstacles impeding full gratification of wants. The positive and negative aspects of relationships-their character as instruments of, and curbs upon, human cravingsexplain the contradictory impulses they evoke: the ambivalence of affection and hostility in the family, organizational loyalty and factionalism in the fraternal association, consecration and revolt in the church, friction and collaboration in the shop.

The wants for which the individual seeks satisfaction possess social as well as biologic determinants. Food is an elemental need; but the type of food any given man finds satisfactory reflects the customs of his culture, the gustatory predilections of his family, the standards of his class, the ambitions for advancement symbolized by ability to purchase foods deemed "better" in his society-and, as the line of interaction turns back, the peptic ulcers or other illnesses he may acquire under the stresses and strains of the struggle to "get on"! And so with other needs and cravings.

In their turn the obstacles rising in the way of satisfactions and life-goals may be internally or externally generated. The pay-envelope earned on the job, for example, with which the individual purchases these multiply-determined goods and services, may never seem sufficient to maintain him in the style to which he aspires. But its inadequacies too will almost always prove overdetermined-a resultant of many varying influences rather than of any single or clearly objective one. Even when earnings are inadequate, as, for instance, in a substandard industry, or in a depressed region, or on short-time, or during a period of inflated prices, the tensions of the real pinch are accentuated by contrast of the wage-earner's lot with the vaunted American standard of living, with the position of workers in higher-wage industries, or with family ambitions. In the same way, even when subjective inadequacies contribute to low earnings-lack in skill, personality handicaps, neurotic difficultiesonce more the environmental pressures that induce high aspirations sharpen the resulting discontents. Just so the able, superior man, quite as much as the average American who is far and away the highest-paid worker in the world, seldoms feels he is getting all he needs or deserves.

\section{III}

The American, in a word, descendant of forbears with the drive to uproot themselves in search of a new life deemed better than the old, is now also child of the society thus built, with its prestige values attached to material success, and its competitive urges to do as well as or better than the next fellow. Pushed and 
pulled by a multiplicity of internal drives and external pressures, he brings to his job all those concentric circles of relationships of which he is so integrally part and which are so inextricably part of him-family, kinfolk, age-group, neighbors, union fellows, church brethren, culture-complex, etc. To satisfy the varying expectancies revolving about him within these circles of relationships, he looks for certain jobreturns. By the sheer fact that he spends a good part of each day on the job with other men, he becomes part of still further relationships. These shop relationships in turn bring satisfactions, or tensions and discontents.

Manifestly an obstacle to individual gratification rising anywhere in this intricate chain of relationships, reaching from outside the shop to the job and back outside again, may underlie shop friction-and then disputes. Wherever they arise, however, such obstacles reflect the social complexities of present-day living: they present themselves as unsolved problems or frustrating situations or conflicting urges. The specific forms of resistance and aggression they then evoke within the shop take on the characteristic impress of its relationships. The familiar slow-down, for instance, so troublesome an expression of shop friction, represents a protective device of the group, enforced by various group compulsions, against individual fears of working oneself out of a job or into a rare-cut, and so into hard times in the home-a comlex response to a complex danger spelled out on some uncanalized line of communication that transmits the suspicions crystallized out of varied work experiences. In the relationships binding employer and employees, in a word, the frustrations and conflicts evoking hostile impulses find outlet in the resistances that comprise shop frictions.

The formation of these relationships begins with the moment an individual is placed upon the payroll. For he is then also placed in a defined position in relation to all the other people in the shop. Numerically most of them work at the base of an authoritarian hierarchy. They are "subordinates" who must take orders from, and satisfy by their performance, a "superior" immediately "above" them. This "superior" in turn also takes orders from the man "above" him in the line of authority. 1

The authoritarian character of the shop derives, of course, from the very nature of modern industry. When finished goods are produced by assembling many separate parts turned out by many different workers, when those goods reach the consumer through the departmentalized functions of purchasing, engineering, production, accounting, selling, etc., the chain of activities manifestly requires continuous direction. Only a disciplined work-community can turn out goods under such conditions. Technologic industry itself makes imperative the need for the authority by which management imposes its commands upon workers.

These technical justifications of management's "rights" to manage, however, do

1 Burleigh B. Gardner, Human Relations in Industry (1945) r-64; Gardner, The Factory as a Social system, c. II in William F. Whyte (ed.), Industry and Society (I946). 
not mitigate the human tensions and resistances induced by the exercise of these "rights." It is true that the manner of exercising authority exerts important influence upon the responses to it, just as it is also true that the capacity to accept authority and submit to disciplines imposed from "above" varies from man to man. But generally the sense of imposition evokes resentments. Only when he who takes orders feels some identification with him who gives them-when he shares common codes and goals-does authority become acceptable and discipline merge into selfcontrol. American workers, and their superiors, all usually want to "make good" as individuals on their job. Typically they need the job to support themselves and their families; they want to earn "more"; they hope to advance and "get on." But the measure of their success is defined by the judgment of an immediate superior. How that superior feels and acts each day, what he says and how he says it, what he might have meant by what he says, what he might think about something that may have gone wrong-all become matters of intense concern to the "subordinates" on the job.

The prime significance of these job relationships explains the pervasive suspicions of "favoritism"-suspicions that have played a long familiar part in creating shop frictions. Whenever an individual fails to derive all he desires within a given relationship, he easily ascribes the frustration to favoritism. Even in the family a child may feel sharp jealousy of a sister or brother to whom parents seem partial. Not that the "boss" may never be guilty of favoritism; but just as often the suspicions may represent nothing more than suspicions-an index of dissatisfactions and frustrations in the relationship with a superior upon whom so much of vital importance depends.

Job content may further aggravate tensions and discontents. For great numbers the job is physiologically and psychologically unsatisfying-a barren, boring stretch of monotony. Yet too often the boss spurs the drive for "efficiency" by every possible incentive but the effort to make work itself interesting. And thus it is that the magnificent tools of technologic industry evoke no sense of personal pride and identification in the men who use them; while the magnificent mastery over nature these tools have yielded fails to impart any sense of the individual effectiveness that proverbially has constituted a potent reward to man for the toil and sweat of labor. This lack of intrinsic satisfaction in work is easily transformed into resentments against the boss who must keep the worker at it.

Nor, unfortunately, does "keeping him at it" possess even the mitigation of permitting a man to settle comfortably into familiar, accustomed grooves. For change, however erratic its rate in any given shop, is the one sure constant in modern industry, embedded in the very nature of technology. Only continous improvements in techniques and methods make possible a steadily rising standard of living. Recurrently such changes may spell economic disaster to the men directly involved: displacement, dilution of skill, decline of earnings. Quite understandably, therefore, 
any projected shop innovation may easily evoke the fear and sense of threat that mobilize resistance, and so generate frictions between management and men.

And not only technologic change but all change, sheerly as change, creates dislocation and disturbance. A new top management sounds an alert throughout the structure of shop relationships, until all levels in the hierarchy of authority, from the working ranks up, have determined the manner of men who have taken over "headquarters." The appointment of a new foreman sets up its interacting pattern of initial tensions as the men whom he will supervise warily take his measure, while he himself braces to make good on his job. Even the appearance of a new worker at the bench may unloose a chain of negative responses. Those already on the job size up the newcomer to determine whether he will play the group game; the newcomer for his part feels the typical uneasiness of a stranger entering any settled or going association. For employees, just as men combined in any organized activity, tend to cross the formal lines of association with spontaneous allegiances. Workers at the bench do not function as discrete individuals solely in the shop positions to which they are formally assigned.' Instead they coalesce into small bench groups, united for resistance-maintenance of a standard day's work, slow-down, rejection of an innovation, covert struggle against whatever or whomever the group fears and dislikes-or, though unfortunately far less often, for zestful work co-operation.

Upon this structure of shop relations with its group codes, its systems of values and beliefs, its symbols of rank and role, its "cake of custom" as well as its rules of law, the larger outside community impinges unceasingly and inescapably. Legal reform, union organization, urban problems, general social upheavals form swift currents of external influence that beat upon the going shop community. In contrast to the adjustments demanded of workers by internal innovations and shifts, it is management that usually finds itself on the receiving end when these external forces buffet a shop. Under their impact the employees or their spokesmen-political as well as union-seem the aggressors against customary usage and "right" ways of behaving. We are still close enough to the ferment of New Deal reform, of swift union growth under the aegis of the Wagner Act, and of the spread of socialist and communist economies in our war-devastated world to realize vividly how emotion-loaded these great social changes have been for management. And just as workers project their uneasy fears, their sense of unmerited injury in changing shop relationships, upon industrial authority, so management displaces its hostile impulses upon the union "boss," the labor "monopolist," and "ungrateful" employees. Where one side denounces Congressional "reactionaries" and the "bour-

${ }^{2}$ See Elton Mayo, The Social Problems of an Indestrial Civilization (i946), chaps. i-2; F. J. Roethlisberger and Williak J. Dickson, Management and the Worker (r939) pts. IV and V, 379-604; Burleigh B. Gardner, Human Relations in Industry (1945) 65-95; John B. Fox and Jerome F. Scott, Absenteeism: Management's Problem (Harvard University Business Research Studies, No. 29, 1943); Elton Mayo and George F. F. Lombard, TeAMwork and Labor Turnover in the Aircraft INDUStry of Southern Califormia (Id., No. 32, I944). 
bons," the other fulminates against "that man in the White House" and the Washinton "bureaucrats."

It has been through the entry of "outside" unions into hitherto unorganized shops during the past decade that the most pronounced seismographic shocks have been registered throughout industry, precisely because labor organization and collective bargaining effect a profound social change in the established shop community. The ferment and frictions so commonly experienced in the initial stages of joint dealings are an index of the deep-reaching dislocations consequent upon this transition. ${ }^{3}$

For the basic structure of authoritarian relations has been shaken. Foremen and supervisors generally feel their established shop roles threatened; management mobilizes to defend from the ever-encroaching "usurper" the prerogatives deemed essential to effective performance of its industrial role. In truth, the familiar "right" to give orders from "above" to the "ranks" has been made subject to new "rights" of scrutiny and challenge. Those empowered to apply the new rights occupy newly created roles in the now branching lines of authority: shop stewards, union field representatives, union headquarters officials. They function under jointly formulated codes of shop law embodied in the collective agreement. The union organization, with its history, traditions, and current modes of behavior crystallized out of the specific group experience, takes its place beside the company organization as a constituent part of the whole structure of shop relations. The union factions operating within the union organization supplement the bench-and office-cliques functioning within the plant. The entry of the union neither creates these shop groups, nor does it dislodge them; although they too may now be variously transformed by assimilating into their cohesive clique associations the systems of belief and the new instrumentalities of unionism. At any rate, if frictions stem from the negative impulses evoked within the structure of relationships binding management and men in any shop, so profound a transformation of that structure as the entry of a union entails understandably intensified friction until the new relationships have become the accepted, customary ones.

\section{IV}

To spell out the dynamics of shop relations in such detail for an analysis of friction involves its hazards. Such formidable causative factors may make the requirements of dealing with problems of friction appear overwhelming. Yet the adamant fact remains that nothing less than full understanding of these complexities can serve the needs of effective policy. If, in a word, shop frictions are functions of shop relationships-of the hostile impulses evoked in men by their typical activ-

\footnotetext{
- For an extended treatment of the subject see the following series of papers by Benjamin $M$. Selekman, shortly to be issued in book form by McGraw-Hill Co. under the title Lamon aND Humas ReLations: When the Union Enters (1945) 23 Harv. Bus. Rev. 129; Administering the Union Agreement (1945) 23 id. 299; Handling Shop Grievances (1945) 23 id. 469; Resistance so Shop Changes (1945) 24 id. I19; Wanted: Mature Managers (1946) 24 id. 228; Wanted: Mature Labor Leaders (1946) 24 id. 405; Conflict and Co-operation in Labor Relations (1947) 25 id. 318.
} 
ities on the job-everything affecting those relationships possesses its potential for intensifying or reducing the resistant behavior that comprises friction. There is no escape from the reality that labor relations encapsulate all the psycho-social influences shaping job behavior-influences ranging from the close concerns of family and kin, through the tense uncertainties of the actual shop community, to the diffuse encirclement of our whole changing society.

Thus it is that shop friction-natural, everyday, garden-variety phenomenon in work-behavior though it is-does not lend itself to facile, ad hoc administrative attention. Efforts to deal now with this resistance and now with that, now with one "agitator-type" and now with another "hard-boiled" supervisor, now with one union "autocrat" and now with another "troglodyte" in management, miss the fundamentals of the continuing problem. But if the approach through relationships discourages confidence in specific formulae or hortatory recriminations, it also indicates the focus of remedial action. Improvement in shop relations alone promises a diminution of shop friction.

That so many wide-reaching external forces find their reflex in shop behavior in no way counters the validity of this guide for action. For instance: a soundlyfunctioning economy within which employees obtain steadily increasing security, rising standards of living, and good job opportunities certainly constitutes a basic condition of stable labor relations. It is also certain that no individual manager, no local union administrator can as an individual and alone assure the establishment of these communal prerequisites of co-operativeness in the shop. None the less, if an administrator succeeds in building good relationships with the men he-leads, his local shop community proves better able to withstand whatever stresses may bear upon it. This is true of any social institution, as the experience of families during the depression of the Thirties shows. When the ties between husband and wife, parents and children were strong and positive, the family unit they composed came safely through the economic stresses under which a weaker one broke. ${ }^{4}$ In the same way a shop community in which management and men, union and company have established relationships of mutual trust and understanding will be less affected by adverse external influences than one in which fears, suspicions, and tensions run strong in the currents of daily dealings.

Granted this crucial significance of local shop relationships, the reciprocal also remains true: if sound relations are to be developed, objective conditions in the immediate work environment must meet the test of communal judgment. The sweatshop, the speed-up, the sub-standard wage, hardly help create the kind of work environment in which the administrator may build positive shop relations. Fortunately American management shares widely with unions today a belief in high wages, rising living standards, good work conditions, etc. This communal code; so to speak, expressing the American economic faith, may put a floor under shop

- Robert Cooley Angeld, The Family Encounters the Depreschon (1936); Ruth S. Cavar and K. H. Rancx, The Family and the Depression (1938). 
frictions, just as public sanitation, the first essential of preventive medicine, puts a floor under personal illness. Measures for improving shop relations may then become instruments for reducing those frictions that remain to exacerbate dealings between management and men.

\section{$\mathrm{V}$}

If this analysis is valid, and if friction and disputes, distinct phenomena though they are, represent also dynamically related types of behavior emerging out of the continuous flow of shop relationships, is not our first question this: Can the now familiar procedures developed for handling disputes be utilized for dealing also with the "precursor-behavior" comprising friction? These procedures-grievance adjustment, contract negotiation, contract administration, union-management cooperation in its evolving forms, and so on-are tools, of course, that have been developed as part of collective bargaining. But this origin in no way militates against their more comprehensive uses to industrial relations. For one thing, the unionized shop has now become by public policy the dominant pattern of relationships in the basic industries upon which the American economy hinges. The types of labor disputes arousing major public concern accordingly are those arising between $\mathrm{em}$ ployers and the unions speaking for their employees. By the same token the frictions that precede disputes attain particular significance as they are encountered in the current framework of collective dealings. For they guage the quality of underlying relationships in the grass-roots shop where those currents of human feeling and belief take their rise that either make collective bargaining work from day to day-as all concerned still hope it will work in the United States-or silt up the flow of daily dealings until production is obstructed by still another flood of damaging disputes.

Are the administrators in industry, then, obtaining from the procedures of collective bargaining the full measure of controls upon shop behavior potential in them-and if not, why not? Such questions have a familiar ring; the arena of collective bargaining resounds with them. But exhortation, condemnation, recrimination drown out any real probing in what is specifically asked: How can unions be forced to deliver observance of the contracts they sign? How can men be prevented from staging illegal walkouts instead of submitting their complaints to the contractual grievance procedures? How can negotiators, on both sides of the conference table, be compelled to bargain in good faith?

Attempts at answer take varying directions. For some only legal controls offer promise: penalties for infractions, curbs on abuses, restrictions on union activities. For others "better" leadership seems essential: union officers must become more responsible, less power-driven and competitive, more courageous in disciplining their union members; or management must really accept collective bargaining, restrain its "greed for profits," discharge its responsibility to the whole economy by "maintaining purchasing power." Still others see the answer in time, time for the swift 
growth of union organization to settle down into stable, accustomed relationships. But few have begun to inquire into collective bargaining too as a species of human behavior, with its characteristic procedures operating within the characteristic context of the shop community.

It is the simple thesis of this discussion that the behavioral approach is the only thoroughly realistic one, and the only one that promises maximum utilization of these collective procedures, whatever the frame of legislation within which they will operate. Just what, then, does this approach demand in daily practice?

Consider first the grievance procedures. That this adjustment machinery constitutes the heart of the joint agreement has become a truism. But typically consideration and disposition of the shop complaints submitted to it are held within such narrowly legalistic bounds that frictions inevitably have no chance for recognition, let alone attention. For the grievance procedures are operated as a form of sieve by which the "legitimate" shop complaints can be separated from the "invalid." Legitimacy is equated with the ability to prove the right to consideration by reference to a stated clause in the written agreement-an arguable charge of contract violation. Grievances establishing such title to joint consideration are deemed "admissible' for handling by the adjustment procedures.

Let it be granted at once that such preliminary sifting and testing must always constitute the first step in dealing with shop grievances. But what does one do with the "invalid" grievances, the complaints for which no title to consideration, or only a dubious one, can be established within the definitions of the contract? Inder normal practice those complaints are either "dismissed" from any consideration at all, or after consideration are "denied." But do the dissatisfactions they symptomize necessarily disappear because they have been pronounced not susceptible of treatment by the legalistic remedy the aggrieved has demanded? The experienced administrator knows only too well the answer. Until the dissatisfactions have been traced to their source and effectively handled, the shop continues to face the frictions that either crystallize into repeated differences and disputes, or simmer as shop unrest, "illegal" walkouts, absenteeism, insubordination, slow-downs, and clique hostility. No complaint, in a word, as a symptom of human dissatisfaction rather than a claim for "legal" remedy, is ever really "dismissed."

Manifestly the joint grievance procedures will yield their fullest usefulness when they become not the sort of legal sieve they have too long been made-the instrument for separating "valid" from "invalid" dissatisfactions-but rather a means for determining discriminatingly how all dissatisfactions should be handled. Those that must be denied the right to legal remedy remain still matters of concern. The responsible official must seek to discover the sources other than the objective shop

The invocation of time and patience as stabilizers in collective dealings possesses its measure of validity. For with time the new relationships become the accustomed ones; like any social community the unionized shop acquires its own rules and laws and customs and disciplines to which men conform because they have become established and habitual. But beyond these ameliorations of time, we still need to discover how the transition can be accelerated, and desired relations purposively constructed. 
conditions originally protested from which these "invalid" dissatisfactions stem. In terms of these likely causes he applies such tools, other than legal adjudication, as may appear promising in their treatment.

It would be comfortably reassuring if, at this point, we could marshal a whole kit of such tools. Unfortunately, however, all such measures now available are yet tentative and experimental, simply because the social sciences from which they are derived are yet in their early stages of development. But they do exist, if only in a still formative stage of development. One of these is the interviewing or counseling orientation. The administrator-on the union or management side of the joint machinery-learns how to listen rather than argue with a complainant. As he listens, he tries to spot "human," that is, subjective or psycho-social, facts, as carefully as objective or legal ones. He does not tell the most irritating "griper" to "stop talking nonsense." Instead he watches him as any "repeater" should be watched, simply because repetitiveness in negative human behavior constitutes a symptom of something wrong somewhere. Nor does he "soft-soap" or appease the inflammatory militant. But he recognizes excess too as a symptom. The man who inflates complaints and enlarges upon his wrongs as he tells them may be obsessive, or politically ambitious, or a party-line manipulator. The militant, moreover, often becomes more than an individual problem because typically he seeks to make himself spokesman for a bench group, or a department. Individual and group relationship, pressures and conditions in the shop and outside, all mark the friction points at which the responsible official watches for symptoms indicating possible trouble ahead.

When a particular employee or supervisor seems such a "friction point," the administrator of the grievance machinery who has been instructed in listening carefully to men's complaints has also the advantage of continuing relationships with the disturbed and disturbing individual. In so far as the relationship is good and perceptive, he is likely to know something of the personality of each complainant, and even of possible stresses and troubles facing him outside the shop. His sympathetic listening may by itself afford relief to the aggrieved, if only through the process of helping him "get a load off his chest." The process, moreover, conduces toward good relationships, if only because bonds are strengthened by the conviction of "mattering" to one's fellows and superiors. And strong, positive shop relationships constitute a major instrument for reducing frictions and disputes.

From this point of view it is highly desirable that every shop and every union official have some training in counseling technique. A disturbed complainant may, however, need more assistance than the operating official can give or should give. Reliance should then be placed upon trained experts, either on the staff or in the community, to help such an individual discover the source of his dissatisfactions and thus gain insight into his true problems of adjustment. ${ }^{6}$

- See Roethrisberger and Dickson, op. cit. supta n. 2, 189-376; Carl R. Rocers, Counselino and Psychotherapy (1942); Franz alexander, Thosias Morton French et al., Psychonnalytto 
Needless to say, the shop can never become a mental hygiene clinic; its daily work demands an exacting, disciplined and virile structure of job relationships. But even war experience indicated how relevant such counseling skills could be for satisfactory military performance; their varied peacetime applications have proved themselves in education, social work, and neighborhood centers. Should not these skills be thoroughly explored also in industry?

In much the same way, all cases submitted for "legal" remedy should be scrutinized for the information they can yield on bench associations in the plant: Is a complaint prosecuted by a group of employees; do such groups appear with marked frequency before the adjustment machinery; does a complainant function in his grievances as spokesmen for fellow employees, and so on? Once more such social data must be traced back to their sources. Recurrent complaints from a given department, for instance, may prove rooted in really objective difficulties-an inequitable rate schedule, or a bad flow of materials, or the impact of disturbing plant changes, or some other such cause. Or they may reflect the sheer militancy of a clique or faction, led by an employee avid for leadership; or disturbed relationships with foremen, or something else again of this sort. Awareness of such groups then can implement the effort to promote co-operation.

For although the grievance machinery thus uncovers negative feelings and resistant responses, the very process of dealing with them should clear the way for eventual co-operation. The actual evocation of positive sentiments, however, transcends the adjustment procedures; its instruments are found in contract negotiation, in production planning, in general shop administration. Yet as the focus of concern thus passes from handling complaints and dissatisfactions communicated through the adjustment machinery to the promotion of co-operation, there should be no sharp separation of functions. In terms of underlying relationships all such processes are vitally interrelated parts of an organic and dynamic whole.

Too often, however, effort concentrates on setting rigid boundary lines between these processes. Within the system of law and order established by the joint agreement, of course, such divisions have their recognized uses: certainly distinctions must be drawn between the application of existing law and the making of new law. But in their social and psychologic content the revisions of terms negotiated across the bargaining table time and again reflect unsettled grievances carried forward from the expiring agreement; they also furnish opportunities for the participation and consultation that carries back collaborative sentiments to joint dealings. Just

\footnotetext{
Therapy (1946); Burleigh B. Gardner, Human Relations in INdustry (1945) 168-255; ANmette Garrett, Interviewnin-Its Principles and Methods (1943); Personnel Counseling-Key to Greater Production, U. S. War Dept., Civilian Personnel Pamphlet No. I (1943); Proceedings of the Natronal Conference of Socral Worx (1943) 216-236. A sample of periodical literature might include: Burling, Mental Hygiene in Business and Industry, Mental. Hygiene, April, 1941, 177-187; Menninger, Psychiatry and the War, ATL. MoNrhLy, Nov., 1945, 107-114; Gage, A Foundation for Industrial Counseling, The Family Journar of Soctal Case Worx, July, 1942, 176-182; and Gage, Bringing Case Work to a Labor Union, id. May, I945, I06-1 x 1.
} 
so the administration of contract provisions should involve more than the correction of infractions.

Every practical administrator familiar with the negotiatory process can cite evidence demonstrating its continuities with concrete experiences behind the men at the bargaining table. Close scrutiny of the dissatisfactions brought to light by the grievance procedures, accordingly, should serve as excellent preparation for meeting demands likely to be raised during the next negotiations. The completion of the new agreement, in turn, should represent a positive experience for all who must now live under it. For negotiation constitutes a major channel of communication between employer and employees, a channel through which they discuss matters of prime concern in their continuing relations. Yet the actual negotiators often talk more to the press than to their own people. They then discover that an agreement handed to men "on a silver platter," or formulated for them by "top" officials, carries little effect beyond the sense of victory or defeat-again a conflict emotion. Only participation in formulating and determining the issues thus brought into the open carries back into daily shop dealings the sense of direct responsibility for making the settlement work. The special meetings at which some companies (though too few) seek the judgment of their supervisors before negotiations upon the probable issues of the conference room, and after the agreement has been drawn discuss application of its terms, are vehicles of such communication and participation. Some unions too-though again too few-convene membership meetings to receive reports upon the progress of negotiations, as well as to ratify the final terms. Joint commemoration of the new shop "constitution," when its completion is jointly commemorated at all, is even more widely limited to the top negotiators. But always, and inevitably, the disregard of negotiation as a positive social experience, the concentration upon it as a legalistic tug of conflicting interests, forfeits an opportunity for both reducing frictions and evoking the co-operative sentiments.

In much the same way, daily administration of the terms of agreement should become more than fair maintenance of a status quo. The negative sentiments evoked by infractions can and should be resolved, of course, by adjudication. But at each of the foci of relationships important enough to receive joint contractual safeguards, the parties should ponder also means for evoking the positive sentiments that engender co-operation-the vivid sense of joint interest, the participation and consultation that build conviction of "mattering" on the job to the whole shop community.

Consider, for instance, the most emotion-loaded issue of contract negotiation: union membership as a condition of employment. Admittedly it is impregnated by the clashing values of the parties; it is also an instrument of the conflict over power and organizational security. Naturally, therefore, it gives rise to the sharpestedged kind of frictions and disputes. But strategic problems of human relations remain for the parties to an agreement beyond any "settlement" on this issue they may. write into its terms. Does the union which has been granted any variant of 
"union security" make union membership a positive experience for the workers? Or does the company make their association in the shop community a true job fellowship? The "join-up-or-else" approach creates little more warmth for union affiliation than does the perfunctory assignment to a work place for the job. Union officials worried over "nickel-in-the-slot" members who want always to know "what they are getting for their dues" need to ponder ways for making the act of affiliating something more than compulsory initiation for a fee; just as the employer, embittered by the lack of loyalty his employees manifest, needs to probe the sources of that sentiment in modern industry.

The creation of positive relationships, in a word, requires systematic planning. Such systematic planning in the human affairs of the shop should continue from the time of hiring, through placement, training, acquaintance with the whole process of which any specific job is part, to every aspect of the production program. Few managements today have to be persuaded that the economic and technical aspects of production programs demand careful organization and planning; they have yet to realize, however, that the human impact of the measures they contemplate can stymie results or advance them. Careful provision must be made against the suspicions, fears, and resentments they may evoke; careful watch must be kept for sources of mutuality and co-operativeness. The men who do the work must constitute as integral a part of the planned production program as the materials on which, the machines with which, and the market conditions within which they labor.

Thus the administrator who must introduce any change into his shop-be it new equipment, or new methods, or a shift in product, or a new supervisory force-must prepare for the jolts that may be transmitted throughout the established structure of relationships. The sense of threat, the alerted, wary suspicions may be counteracted by thoroughgoing preliminary explanation and consultation-with union officials, with bench representatives; while either the union or a management spokesman, or both, discuss every aspect of the projected program with the men involved.

Beyond such general preparation, management should avoid the "friction-points" marked by prior shop experience. A worker who tends to be grievance-prone, or rigidly "set in his ways," is not, for instance, chosen as major testing ground for an innovation-the pilot employee, so to speak. For in the general atmosphere of wary watching, such a man easily galvanizes the suspicions that become resistance to the change; a hostile bench group may readily form under his leadership. To deflect such group hostilities is more difficult than to prevent them.

The next, and even more important effort, however, the transformation of such cliques into co-operative work teams, the constructive utilization, that is, of the impulses binding men at work together into bench associations, presents probably the most difficult problem of modern labor relations. What is required, above all, are supervisors and stewards who evoke positive sentiments and shop loyalties from the men they lead. For only to the degree that foremen on the one side and stewards 
on the other are truly leaders of men will bench groups and shop teams tend to coalesce around constructive goals. The spontaneous associative impulses of the men at work will not then mobilize behind resistance to production policies; while the steward will find it easier to identify union policy with joint interests. It is sometimes amazing to the impartial observer to note the truly explosive appointments a management makes, only to register surprise or outrage later at subsequent eruptions. An employee of German extraction, for instance, was made foreman of a department dominated by Italian employees. Granted that national extraction must not count in promoting men, the new foreman nevertheless had made no secret of his general disdain for the men whom he supervised. His daughter was married-unhappily - to an Italian; he derided the fighting qualities of the Italian arm of the Axis; he described himself as "the only white man" in his shop. $\mathrm{He}$ did not last long as foreman; yet before he was demoted the sparks that flew between him and his men demonstrated the inevitability of dangerous friction in such relationships. In another plant, a white worker was promoted to foremanship in a department where the majority were Negroes. He had been articulate in expressing racial prejudice. The frictions that followed his promotion reverberated throughout the plant, and culminated finally in physical assault upon this foreman himself.

All such considerations simply reflect the kind of purposive attention the structure of relationships must receive if frictions are to be minimized and co-operation enchanced. It is impossible to exhaust the varying combinations of detail in which the general problems present themselves within each specific shop context. But as long as the administrator remains aware of the complex motivations behind the job behavior of his employees, as long as he sees them not as discrete numbers on a payroll, but as the associative, socially interacting human beings they are, he will learn what to avoid and what to neutralize, what to stimulate and what to promote. Just as he detours the negative "friction-points" in shop planning, he provides positive channels of activity in which interest in the job attains expression that manifestly "matters" in the whole production program: he invites participation in planning and improving the job; he promotes understanding of the process into which that job must fit, and familiarity with the final product as a result of cooperative labor. He makes the achievements of the shop community something to be shared by all, perhaps even through appropriate ceremonials. Tentative beginnings in this direction were made during the war through E-awards, visits by war heroes, and communal ship launchings. What symbols may prove appropriate to peacetime production remains to be explored. But the problem has yet to receive even adequate recognition.

Such symbols of work achievement, needless to say, do not replace the tangible rewards of the pay envelope; they supplement and coexist with them. Indeed, pecuniary rewards themselves constitute a major symbol of achievement in our society, so interlaced with, so integral to, the social organization of American pro- 
duction that the impact of the pay envelope can never be minimized. But here once more we confront the thesis with which we began. Simply because friction and co-operation both are functions of shop relations, the one of their negative, the other of their positive components, everything that affects those underlying relationships bears its impress on daily job behavior. The pay-envelope exercises certainly potent effects upon the shop community, as does the manner of introducing changes, the exercise of authority and the imposition of discipline, the attitude toward the individual employee and the work group, the maintenance of job interest and work satisfaction, and so on. Even the home community within which a shop is located transmits its influences to job behavior. Snarled transportation facilities, bad housing, racial antagonisms manifestly are reflected in the relationships of men who are fellow-citizens as well as fellow-employees. That is why joint efforts toward making the hometown a better place in which to live also promote mutuality in the shop. The growing participation of management, unions, and employees, for instance, in community funds and social planning has its reflex in teamwork on the job. Men who work together in civic concerns cannot help but co-operate better in the shop.

\section{VI}

Clearly, then, every industrial administrator, whether on management's side or the side of the union, must watch for and utilize every opportunity to cement and improve relationships. The approach of the union official in this mutual responsibility, however, naturally differs from that of the company executive. For although both share the joint stake in efficient production and human satisfaction, the manager functions from day to day pre-eminently as an administrator; he does a good job when he combines most effectively the men, materials, and machines by which he turns out goods or services. In contrast, the union official is a political representative of men associated in a protest organization. He is constantly under pressure to increase material gains for his men. To maintain the solidarity of his ranks he is tempted to rely upon appeals to the hostile impulses that create frictional resistances and disputes. They are more easily evoked than the positive responses of teamwork; union men, like so many others, are more accessible to appeals "against" than to appeals "for."

We are not without signs, however, in spite of the tensions of the postwar transition, that union leaders are increasingly recognizing their stake in co-operation. The strikes in 1946 in the basic, mass-production industries obscured the fact that in thousands of shops union and management negotiated contracts without fanfare and without stoppages. The negotiations of 1947 even in heavy industry promise to unfold in a much less war-like atmosphere. Some labor leaders, moreover-as in textiles and in the needle trades-have never receded from their conviction that only by co-operation with management can the high standard of living potential in the American economy be realized. 
As collective bargaining matures and stabilizes in the United States, it is to be hoped that ever-growing attention will be devoted to the construction of positive relationships in the grass-roots shop. For only through such relationships may frictions be held to a minimum and teamwork promoted. Some frictions will always remain. For relations between management and men contain not only legitimate economic differences, but also the tensions generated in all human relations. We may as well accept frictions as a fact of industrial life that cannot be completely eliminated from the shop, but can only be handled-or mishandled. If, and as, we learn to handle them with skill and understanding, we shall discover that co-operation too is a fact of industrial life. 